\title{
Significance of K-Ar dating of very low-grade metamorphism in Triassic-Jurassic pelites from the Coastal Range of central Chile
}

\author{
M. BELMAR ${ }^{1}$, D. MORATA ${ }^{1}$, F. MUNIZAGA ${ }^{1}$, C. PÉREZ DE ARCE ${ }^{2}$, \\ S. MORALES ${ }^{3}$ AND F. J. CARRILLO 3 \\ ${ }^{I}$ Departamento de Geología, Universidad de Chile, Plaza Ercilla 803, Santiago, Chile, \\ ${ }^{2}$ Servicio Nacional de Geología y Minería, Santa Maria 0104, Providencia, Santiago, Chile, and ${ }^{3}$ Departamento de \\ Mineralogía-Petrología, Fac. Ciencias, Universidad de Granada, Avenida Fuentenueva s/n. Granada, 18002, Spain
}

(Received 4 June 2003; revised 5 December 2003)

\begin{abstract}
K-Ar isotopic dating of very low-grade metamorphism affecting Triassic-Jurassic rocks in the Coastal Range of central Chile was carried out on whole rocks and their $<2 \mu \mathrm{m}$ size fractions. In the study area, a regional-burial low-grade metamorphism at anchizone conditions $(T$ $\left.\leqslant 190^{\circ} \mathrm{C}\right)$ and low-pressure conditions $(P \geqslant 1.3 \mathrm{kbar})$ has been described. Observed temperatures are related to a contact metamorphism produced by nearby Jurassic intrusions, with a $P-T$ estimate at the immediate contact zone of $\sim 650-690^{\circ} \mathrm{C}$ and 4 kbar.

The whole-rock K-Ar age of $174 \pm 5 \mathrm{Ma}$ is interpreted as belonging to the contact metamorphism due to the intrusion of Jurassic plutons $(165 \pm 5 \mathrm{Ma}$ to $175 \pm 5 \mathrm{Ma})$. A time-interval of $\sim 20 \mathrm{Ma}$ between the diagenesis (206 Ma) and the anchizonal very low-grade metamorphism (181-184 Ma) is obtained, and a rate of subsidence of $\sim 120 \mathrm{~m} / \mathrm{Ma}$ is proposed for these Triassic-Jurassic basins. A thermal influence on the burial, very low-grade, regional metamorphism is invoked.
\end{abstract}

KEYWORDS: pelites, K-Ar dating, very low-grade metamorphism, Costal Range, central Chile.

The link between various styles of burial, diastathermal and contact metamorphism with major geodynamic processes represents a complex model in the interpretation of the origin of very low-grade Andean metamorphism.

Illitic clay minerals have been used in several studies to constrain the geological timing of very low- and low-grade events related to hydrothermal episodes in ore deposits and/or heating events, but also in regional overthrusting, faulting and oil and gas migration. In fact, both authigenic illite and mixed-layer illite-smectite (I-S) have been shown to

* E-mail: mbelmar@ing.uchile.cl DOI: 10.1180/0009855043920127 be reliable clocks at temperatures of $<260 \pm 20^{\circ} \mathrm{C}$ (Hunziker et al., 1986), a property that makes them potentially attractive tools for reconstructing burial history. The formation of illite fixes $\mathrm{K}$ during burial diagenesis and illite crystallites retain Ar, which allows this system to act as an isotopic clock.

$\mathrm{K}-\mathrm{Ar}$ isotopic dating of illitic clay fractions has been used by many authors. However, the interpretation of the dates from sedimentary rocks are controversial (e.g. Hunziker et al., 1986; Clauer et al., 1995; Arkai et al., 1995; Zhao et al., 1997; Clauer et al., 1997; Środoń et al., 2002). Two phenomena make such interpretation difficult: (1) the mechanism of illite growth, i.e. the specific nature of the smectite illitization reaction (see Środoń et al., 2002); and (2) contamination by 
detrital mica in a separated size fraction (see Clauer \& Chaudhuri, 1999). According to Clauer et al. (1997), the age deduced by K-Ar isotopic dating could then be intermediate between those of the authigenic and detrital components.

Mesozoic sedimentary rocks and intrusive igneous plutons are widespread in the Coastal Range south of Santiago, but the influence of contact metamorphism in the regional metamorphic evolution has never been studied. The aim of the present research is to outline the time-temperature nature of regional metamorphism using a multimethod approach. This helps to distinguish between regional-burial, low-grade metamorphic events and local contact metamorphism related to the thermal influence of plutonic intrusions. The possibility of discriminating between and dating these two types of metamorphism is relevant because of the widespread occurrence of intrusions in the evolution of the Andean history.

\section{GEOLOGICAL SETTING}

The study area is located in the Coastal Range of the central part of Chile between $34^{\circ} 45^{\prime}$ and $35^{\circ} 20^{\prime} \mathrm{S}$ $\sim 300 \mathrm{~km}$ south of Santiago (Fig. 1). Late Triassic to Early Jurassic marine to continental sediments and Middle to Late Jurassic volcanic rocks are exposed in the region. Sedimentary rocks form part of an almost continuous belt, which is $\sim 60 \mathrm{~km}$ long and unconformably overlies Palaeozoic metamorphic basement (Fig. 1). Tectonic development during the Triassic was controlled by continuous movements and differential uplift of the Palaeozoic basement until at least the Jurassic (Thiele \& Morel, 1981). The western Palaeozoic areas were exhumed faster than the eastern area, on which Mesozoic basin sedimentary rocks were preserved (Thiele \& Morel, 1981). The regional palaeogeographic and tectono-sedimentary evolution during the Triassic-Jurassic resulted in a simple morphology characterized by basins and high topographies. Uplift of the western Palaeozoic basement at the Triassic-Jurassic boundary, resulted in the development of two sedimentary basins, the Vichuquén-Tilicura basin to the north and the Hualañé-Gualleco basin further to the southeast (Fig. 1). The main structures in the sedimentary strata are north-south fold axes and normal faults, which are generally attributed to the reactivation of deep-seated structures in the Palaeozoic basement. $\mathrm{E}-\mathrm{W}$ faulting in the northern part of the Hualañé-
Gualleco basin predates the prevailing NW-SE faulting (Thiele \& Morel, 1981; Corvalán, 1982). No cleavage is visible in the rock sequence of the northern part, whereas an incipient cleavage has developed in rocks of the central and southern parts of the Hualañé-Gualleco basin, indicating an increase in deformation towards the south.

In the northern Vichuquén-Tilicura basin, the late Triassic sedimentary rocks are characterized by a marine sequence of lutites, abundant shales, sandstones and conglomerates (Figs 1, 2). A Carnian-Norian age was estimated by Corvalán (1976, 1982) based on the presence of Monotis. Early Jurassic sedimentary rocks are in fault contact with the Triassic rocks in the Lago Vichuquén profile (Fig. 1), and reach a mean thickness of 850 $\mathrm{m}$ (Fig. 2). They are predominantly composed of black fissile shales with minor sandstones and conglomerates. Palaeontological evidence indicates an Hettangian-Sinemurian age (Corvalán, 1976, 1982). The eastern border of the VichuquénTilicura basin (Fig. 1) and the basement of the Hualañé-Gualleco basin consist of Carboniferous granite. The western border of the VichuquénTilicura basin (Fig. 1) consists of a Devonian and Carboniferous metamorphic basement sequence (Gonzalez-Bonorino \& Aguirre, 1970; Munizaga et al., 1973; Hervé et al., 1982), generally interpreted as a transition from deformed forearcbasin sediments exposed in the east (Eastern series) to an accretionary complex in the west (Western Series) (Hervé, 1988; Martin et al., 1999; Willner et al., 2000).

The Hualañe-Gualleco basin is located between the villages of those names (Fig. 1). The Late Triassic to Early Jurassic sequence of mainly sedimentary rocks reaches a maximum thickness of $2600 \mathrm{~m}$ to the east of the village of Curepto (Figs 1, 2). The outcrops are located at both banks of the Mataquito River. The lowest $500 \mathrm{~m}$ of the stratigraphic pile correspond to the Late Triassic unit and comprise predominantly shales with quartzitic sandstones, conglomerates, subarkoses and subgraywackes. Biostratigraphic evidence (presence of Monotis) gives a Carnian-Norian age (Corvalán, 1976, 1982).

North, to the Mataquito river, the Early Jurassic sequence reaches a thickness of $\sim 1000 \mathrm{~m}$ (Fig. 2), with palaeontological evidence also indicating Hettangian and Sinemurian ages (Corvalán, 1976, 1982). In the south of the basin, $2100 \mathrm{~m}$ of finegrained arkosic sandstones to subgraywackes with 


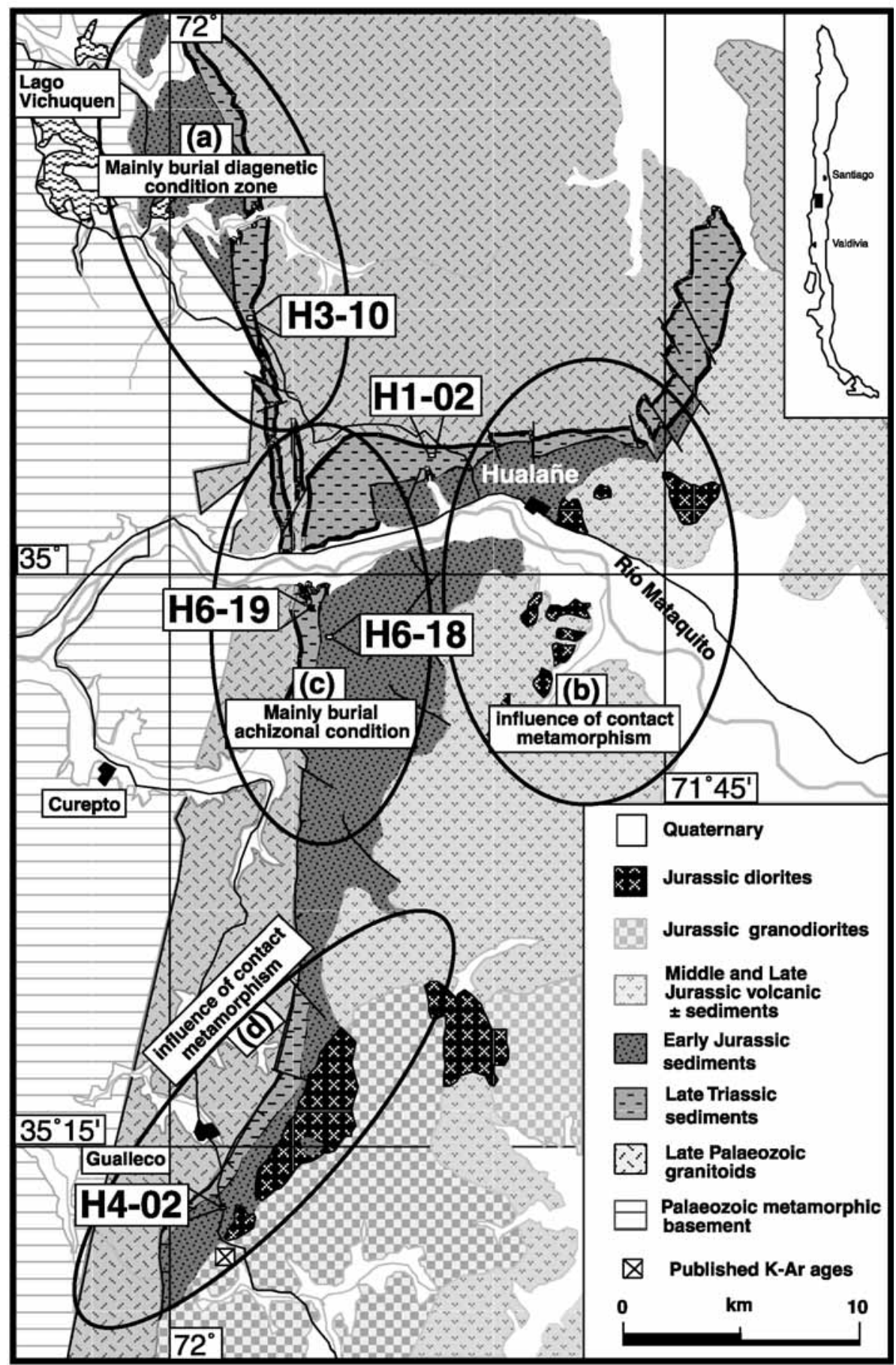

FIG. 1. Simplified geological map of the Triassic-Jurassic formations of the Coastal Range in central Chile at the $34^{\circ} 45^{\prime}$ to $35^{\circ} 20^{\prime}$ S., with location of the Vichuquén-Tilicura basin at the north and the Hualañe-Gualleco basin at the central and south and the analysed samples used in this work. Modified from Corvalán (1994) and Belmar et al. (2002). a, b, c and d: locations for stratigraphic columns of Fig. 2. 
East of Curepto (c)

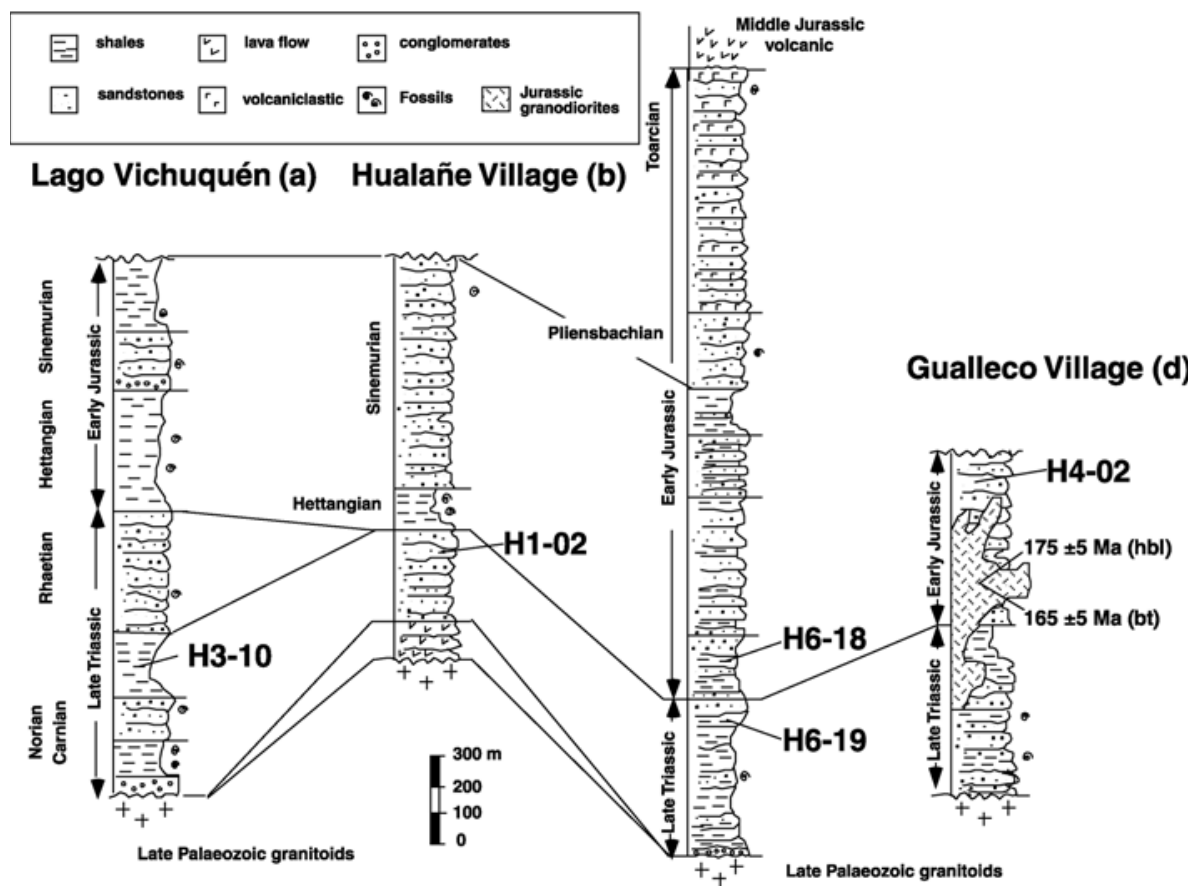

FIG. 2. Stratigraphic columns of the Triassic-Jurassic formations of the four areas marked in Fig. 1 with location of the dated samples. Modified from Corvalán (1994) and Belmar et al. (2002).

minor interbedded fissile shales are present (Figs 1, 2), with fauna indicating a Pliensbachian-Toarcian age. The Hualañé-Gualleco basin is intruded by Jurassic diorites and granodiorites, dated by Gana \& Hervé (1983) at $165 \pm 5 \mathrm{Ma}$ (K-Ar on biotite) and $175 \pm 5 \mathrm{Ma}$ (K-Ar on hornblende). Most of the eastern part of the study area is composed of andesitic lava flows, volcanic breccias and minor sedimentary intercalations of Middle and Upper Jurassic age (Fig. 1), reaching a maximum thickness of $\sim 3600 \mathrm{~m}$ and belonging to the Altos de Hualmapu Formation (Morel, 1981; Bravo, 2001). No isotopic data are available for this unit. However, the upper part of the Jurassic marine unit presents volcanic intercalations of lavas and breccias with green sandstone containing Grammoceras and Hildoceras indicating a Toarcian age for the end of the marine sedimentation. Corvalán (1982) suggested this time for the probable fulfilling or uplift of the basins. In the southern part of the area, the volcanic units are intruded by Jurassic granodiorites with dioritic borders (Fig. 1).

\section{METAMORPHIC EVENTS}

Diagenetic to very low-grade metamorphic $P-T$ conditions have been determined for Late Triassic to Early Jurassic sedimentary rocks from the Vichuquén-Tilicura and the Hualañé-Gualleco basins in Central Chile using illite crystallinity (Kübler Index, KI; Kübler, 1967, 1984), coal-rank data, K-white mica $b$ cell dimension, characteristic mineral assemblages and fluid-inclusion data (Belmar et al., 2002). A burial-related diagenetic to low-grade metamorphic event, recorded in both basins, is partly overprinted in the HualañéGualleco basin by a contact metamorphism around the Jurassic dioritic to granodioritic intrusions (Fig. 1). Diagenetic conditions prevailed in the northern Vichuquén-Tilicura basin, whereas in the southern Hualañé-Gualleco basin, low-grade metamorphism is observed with an increase in metamorphic grade from north to south. Epizonal conditions are reached locally, south of the Hualañé-Gualleco basin. Low-pressure conditions were determined using the $\mathrm{K}$-white mica $b$ cell dimension (mean values of $9.000 \pm 0,004 \AA, n=26$ ). 
Evidence of contact metamorphism in the immediate proximity of some Jurassic intrusions includes: (1) hornfels facies assemblage with ferrosilite $\left(X_{\mathrm{Fe}}=0.6\right)$-magnesiohornblende-ferroactinolite, biotite together with chlorite, plagioclase and stilpnomelane, and (2) natural coke and pyrolitic bituminite in some sedimentary samples. Epizonal KI (according to Kisch, 1991) and high coal-rank values are probably a result of this locally occurring contact metamorphism (Belmar et al., 2002).

\section{ANALYTICAL METHODS AND SAMPLE PREPARATION}

Shales and slates were cleaned from weathering rims with a steel brush, crushed into small pieces with a hammer and $\sim 100 \mathrm{~g}$ of sample were ground with a rotary disk mill. A short milling time was applied in order to avoid fragmentation of coarse grains. Carbonate was removed by treating with $5 \%$ acetic acid and by washing with deionized water. The $<2 \mu \mathrm{m}$ fraction was obtained using settling tubes and Millipore filters with $0.1 \mu \mathrm{m}$ pore size at room temperature on a perfectly even table. The clay fraction was then Ca-saturated with $2 \mathrm{~N} \mathrm{CaCl}_{2}$. Oriented slides were prepared by pipetting suspension onto glass slides $\left(\sim 5 \mathrm{mg} \mathrm{cm}^{-2}\right)$ and allowing to air-dry. Glycolated mounts were prepared in a glycol steam bath at $60^{\circ} \mathrm{C}$ overnight. To perform the illite-muscovite polytype determination, randomly oriented samples were prepared using the technique described by Dalla Torre et al. (1994).

Powder X-ray diffraction (XRD) measurements were performed with a Siemens D-5000 diffractometer (Mineralogish-Petrographisches Institut, University of Basel, Switzerland) using the following instrumental settings: $\mathrm{Cu}-K \alpha$ radiation, $40 \mathrm{kV}, 30 \mathrm{~mA}$; automatic primary and secondary divergence slits; secondary graphite monochromator. The $d$ spacing was calibrated against quartz occurring in the samples.

The Kübler index (KI) was determined as the angular peak width at half of the first illite basal reflection on the $0.1-0.2 \mu \mathrm{m}$ fraction, following the Kisch (1991) recommendations (see Belmar et al., 2002, for details).

The K-Ar dating was performed in the Geochronology Laboratory of the Servicio Nacional de Geología y Minería (SERNAGEOMIN) in Santiago, Chile. Samples were degassed by high-frequency induction heating. The argon was cleaned and purified in Pyrex extraction lines and the radiogenic ${ }^{40} \mathrm{Ar}$ volumes were determined using isotopic dilution techniques in an MS10S Mass Spectrometer, with a total accuracy of $1-2 \%$. The $\mathrm{K}$ analyses were done in triplicate by atomic absorption techniques with an accuracy of $0.7-1.3 \%$, depending on the $\mathrm{K}$ content and using a Li-internal standard. The interlaboratory standard GL-0 was used for controlling and the calibration of $\mathrm{Ar}$ and $\mathrm{K}$ determination. Errors in K-Ar ages are quoted at the two sigma $(2 \sigma)$ level and the decay constants are those suggested by Steiger Jäger (1977). These include a $1.5 \%$ estimated error for the standard GL-0 and a $1 \%$ error for the $\mathrm{Ar}$ isotope ratios. To avoid the disturbing effects of detrital muscovite, only the KAr ages obtained on the $0.1-2 \mu \mathrm{m}$ fractions were used for dating metamorphism, following the practice of Hunziker et al. (1986).

\section{TEMPERATURE AND PRESSURE DETERMINATION IN THE SELECTED SAMPLES}

Based on the previous multimethod study of Belmar et al. (2002), three areas can be established in the Vichuquén-Tilicura and Hualañé-Gualleco basins. Two have $P-T$ conditions typical of burial diagenetic to anchizonal conditions and the other two, of contact metamorphism (Fig. 1). From 71 samples studied by Belmar et al. (2002), mainly shales and slates, a selection of five was made for radiometric dating (Figs 1, 2). The criteria for selection were: (1) age of metasediments, selecting the Triassic (and Lower Jurassic) stratigraphic deeper samples; (2) illite crystallinity, using sampling with KI values indicating anchizonal to epizonal conditions, because the complete removal of the inherited isotopic signature seems to be effective only at epizonal grade (Clauer \& Chaudhuri, 1999); (3) presence of index minerals (mainly the occurrence of characteristic and indicative minerals, paragonite for instance); and (4) clear estimations of metamorphic temperature conditions by fluid inclusions and/or other methods. This selection is summarized in Table 1 and presented in the following paragraph.

The ordering type and the percentage of illite in mixed-layer (I-S) were determined in each sample after the Moore \& Reynolds (1977) method. The presence of the I-S ordering type $\mathrm{R}=1$ with $65 \%$ illite in I-S in the northern part of the Vichuquén- 


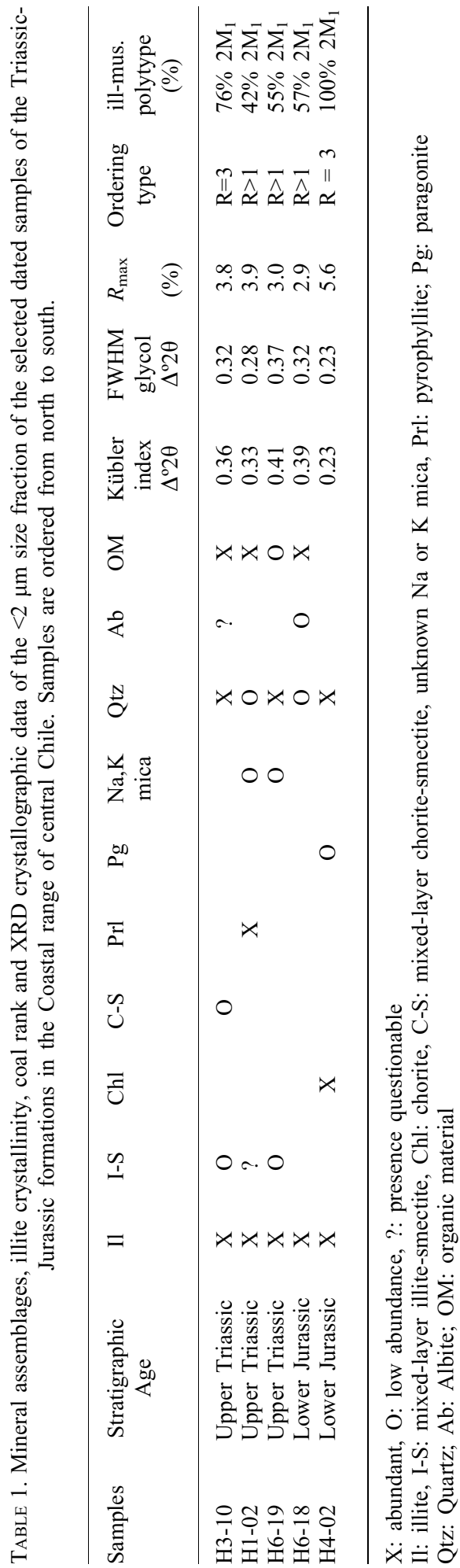

M. Belmar et al.

Tilicura basin (Belmar et al., 2002) contrasts with the presence of the I-S ordering type $\mathrm{R}=3$, with $>90 \%$ illite, observed in the sample H3-10, located in the southern part of this basin (area a in Fig. 1). This occurrence could indicate the beginning of anchizonal conditions, which correlates with the increasing value of vitrinite reflectance in the southern basin. This transformation probably occurred at a temperature of $170-180^{\circ} \mathrm{C}$ according to Pollastro (1993). This condition fits well with other temperature indicators $\left(\mathrm{KI}=0.36 \Delta^{\circ} \theta, R_{\max }=\right.$ $3.8 \%$ for the sample H3-10, see Table 1) and with the proposed temperature for the diagenesisanchizonal boundary.

In the Hualañe-Gualleco basin (areas b, c and d in Fig. 1), a regional low-grade metamorphism is observed reaching low-anchizonal conditions. Close to Jurassic intrusions (areas $\mathrm{b}$ and $\mathrm{d}$ in Fig. 1), a thermal contact metamorphism is also present. The ordering type $R>1$ ( $85-90 \%$ illite in I-S) was only found in this basin (samples H1-02, H6-19 and H6-18), and according to Merriman \& Frey (1999), smectite contents of $1-10 \%$ in mixed-layer I-S from the anchizone samples imply a burial depth of $\sim 5 \mathrm{~km}$ at temperatures between 150 and $230^{\circ} \mathrm{C}$.

The Belmar et al. (2002) data, paragonite occurrence is restricted to samples of the HualañéGualleco basin. The appearance of this index mineral, together with KI and coal rank data, are characteristic of low-anchizone to low-epizone rocks. The temperature of sample H6-18 (LowerJurassic sediments) was estimated to be $>190^{\circ} \mathrm{C}$ as determined by fluid-inclusion thermometry (Belmar et al., 2002). The corresponding fluid pressure determined in the same fluid inclusions is $1.3 \mathrm{kbar}$ corresponding to an overburden of $\sim 4.8 \mathrm{~km}$ and agrees well with the $b$ cell dimension parameter indicating low-pressure metamorphism for this region. These results agree with the measured KI $=0.37 \Delta^{\circ} \theta$ and $R_{\max }=2.9 \%$ values in the same sample, as well as with a sample from the nearby Upper Triassic horizon (H6-19) which gave similar conditions $\left(\mathrm{KI}=0.41\right.$ and $R_{\max }=3.0$ ). Higher metamorphic conditions were determined for sample H1-02 $\left(\mathrm{KI}=0.33 \Delta^{\circ} \theta\right.$ and $\left.R_{\max }=3.9 \%\right)$ which also contains paragonite.

In sample H4-02 (area d, Fig. 1), located south of Gualleco and containing the assemblage chloritemuscovite-paragonite-quartz, the 'chlorite geothermometer' (Cathelineau, 1988) has been applied giving a temperature of $281 \pm 16^{\circ} \mathrm{C}(n=8)$. Even taking into account the limitations of the 
'chlorite geothermometry', the temperature values obtained lie within the range inferred from KI value $0.23 \Delta^{\circ} 2 \theta$ and from coal rank $\left(5.6 \% R_{\max }\right)$.

Very close to some Jurassic intrusions, contact metamorphism is present, as shown by the pyroxene hornfels facies paragenesis and by the natural coke and pyrolitic carbon in sedimentary samples (Belmar et al., 2002). The temperatures of the contact metamorphism were calculated based on coexisting plagioclase $\left(\mathrm{An}_{57}\right)$ and magnesiohornblende with ${ }^{\mathrm{VI}} \mathrm{Al}=0.12,{ }^{\mathrm{A}} \mathrm{Na}=0.94$ and $\mathrm{Si}=$ 7.3 a.p.f.u. (atoms per formula unit) using the amphibole-plagioclase goethermometer of Holland \& Blundy (1994). Calculated temperatures of the edenite-tremolite solid solution lie within a range of 655 to $691{ }^{\circ} \mathrm{C}$ and a pressure of $<4$ kbar. Due to this increased temperature, the sedimentary rocks near this sample show a strong increase in coal rank (up to 6.5) and decrease of the absolute KI (up to 0.20) values (Belmar et al., 2002), contrasting with coal-rank values of 3.0 and KI values of 0.41 in contact-metamorphism unaffected samples (e.g. sample H6-19, sector c in Fig. 1 and Table 1).

\section{ISOTOPIC RESULTS}

$\mathrm{K}$-Ar ages were determined for the whole-rock and the $<2 \mu \mathrm{m}$ size fraction in five samples (Table 2). The isotopic ages range from $559 \pm 16$ to $174 \pm 5 \mathrm{Ma}$ for the whole rocks and from $206 \pm 6$ to $155 \pm 5 \mathrm{Ma}$ for the $<2 \mu \mathrm{m}$ size fraction. For each sample, the
$\mathrm{K}$-Ar age presents a considerable decrease when the age determination was made from the fine fraction. This trend becomes obvious, considering that the $<2 \mu \mathrm{m}$ size fractions concentrate the authigenic clay materials, including the K-rich clay fraction. The main constituents of the clay fractions from the analysed samples are illite, illite-smectite, pyrophyllite and/or paragonite (chlorite is only in the sample H4-02). All these clay minerals are considered authigenic low-grade metamorphic minerals (Belmar et al., 2002). However, contamination by detrital mica in the separated size fractions could never be discarded as could contamination by other detrital minerals and other uncertainties remain about ancient radiogenic ${ }^{40} \mathrm{Ar}$ trapped in the illite crystals.

\section{DISCUSSION}

\section{Interpretation of $\mathrm{K}$-Ar ages for whole rocks}

Some of the pioneer K-Ar rock studies in the 1960s showed a fortuitous agreement between the isotopic dates of sedimentary units and their stratigraphic ages. However, later research revealed that to provide a geologically meaningful isotopic age, the isotopic system of a whole rock needs to be in perfect isotopic equilibrium (same $\mathrm{K}$-Ar values for all their major components) (e.g. Clauer \& Chaudhuri, 1999). For this reason, whole-rock determination are usually unsuitable for dating the

TABLE 2. Results of the K-Ar analyses (age in $M a \pm 2 \sigma$ ) on selected rock samples of the Triassic-Jurassic formations in the Coastal range of central Chile. For each sample, the whole-rock and $<2 \mu \mathrm{m}$ size fraction were dated. Samples are ordered from north to south.

\begin{tabular}{lcccccc}
\hline Samples & $\begin{array}{c}\text { Stratigraphic } \\
\text { age }\end{array}$ & $\begin{array}{c}\text { Size fraction } \\
(\mu \mathrm{m})\end{array}$ & $\begin{array}{c}\mathrm{K} \\
(\%)\end{array}$ & $\begin{array}{c}\text { Ar rad } \\
(\mathrm{nl} / \mathrm{g})\end{array}$ & $\begin{array}{c}\text { Ar atm } \\
(\%)\end{array}$ & $\begin{array}{c}\text { Age } \\
(\mathrm{Ma} \pm \sigma)\end{array}$ \\
\hline H3-10 & Upper Triassic & Whole rock & 1.56 & 26.826 & 4 & $\begin{array}{l}395 \pm 12 \\
\text { H3-10 }\end{array}$ \\
& & & 3.07 & 26.074 & 7 & $206 \pm 6$ \\
H1-02 & Upper Triassic & Whole rock & 3.38 & 30.950 & 3 & $221 \pm 7$ \\
H1-02 & & 3.63 & 26.846 & 16 & $181 \pm 6$ \\
H6-19 & Upper Triassic & Whole rock & 2.61 & 23.570 & 6 & $219 \pm 7$ \\
H6-19 & & & 2.89 & 21.748 & 11 & $184 \pm 6$ \\
& & & & & \\
H6-18 & Lower Jurassic & Whole rock & 1.74 & 44.330 & 5 & $559 \pm 16$ \\
H6-18 & & & 5.76 & 43.272 & 7 & $184 \pm 4$ \\
& & & & & \\
H4-02 & Lower Jurassic & Whole rock & 2.84 & 20.136 & 2 & $174 \pm 5$ \\
H4-02 & & & 2.99 & 18.835 & 21 & $155 \pm 5$ \\
\hline
\end{tabular}


age of diagenesis to very low-grade metamorphism. The main problem is the presence of detrital grains, which partly preserve their radiogenic argon content during transport and re-deposition. According to Hunziker et al. (1986), the critical temperature for total Ar resetting is estimated to be $260 \pm 30^{\circ} \mathrm{C}$, and only above this temperature will full resetting of the $\mathrm{K}-\mathrm{Ar}$ isotopic system be realised.

Nevertheless, when very low-grade metamorphic conditions are below the critical temperature for the total Ar resetting, whole-rock K-Ar age determinations could provide a relative constraint to the provenance source area of the metasedimentary rocks. In this sense, a most obvious way to investigate the significance of the age determination on whole rocks is to compare them with isotopic ages available for the surrounding regional rocks. Two main lithologies are possible source areas to contribute detrital grains to the Triassic-Jurassic sediments: the Palaeozoic metamorphic complex and the Late Palaeozoic batholith. Whole-rock Rb$\mathrm{Sr}$ isochron ages from the metamorphic complex of the western series ranging between 342 and $270 \mathrm{Ma}$ have been interpreted in relation to the timing of the regional metamorphic peak between $34^{\circ}$ and $38^{\circ} \mathrm{S}$ (Munizaga et al., 1988; Hervé, 1988). On the other hand, a K-Ar age of $328 \mathrm{Ma}$ for glaucophane (from a locality a few $\mathrm{km}$ north of the study area, near the coastal town of Pichilemu), and a $322 \mathrm{Ma}$ $\mathrm{K}-\mathrm{Ar}$ age for crossite (from the locality of Cahuil, also few $\mathrm{km}$ to the north of the study area) have been obtained by Hervé et al. (1974). Hervé (1988) published new data ( $\mathrm{Rb}-\mathrm{Sr}$ isochron data) constraining the metamorphic age between 368 and $347 \mathrm{Ma}$ for the higher-grade sillimanite gneisses and to $310 \pm 11 \mathrm{Ma}$ for the blueschists at Pichilemu. However, ages of 210 to 220 (Gonzales Bonorino 1971; Hervé et al., 1982), based on K-Ar determination on blueschist rocks from Pichilemu, indicated a thermal $\left(>350^{\circ} \mathrm{C}\right)$ overprinting in this area (Hervé et al., 1982).

$\mathrm{K}-\mathrm{Ar}$ data of whole-rock analyses from samples selected in this work show scattered ages (Table 2). Two have isotopic ages of $221 \pm 7 \mathrm{Ma}$ and $219 \pm 7 \mathrm{Ma}$, probably indicating the palaeogeographic provenance of the western Palaeozoic metasediments. An age of $395 \pm 12 \mathrm{Ma}$ for the whole-rock analyses in sample H3-10 correlate with the Devonian age of the Palaeozoic batholiths (Willner et al., in press). However, for sample H618 , an older K-Ar age of $559 \pm 16$ has been obtained. This is older than the age of immediate possible source rocks. The nearby Precambrian rocks in the continent crop out in the Argentinean Precambrian Cratonic basement. During the Triassic, this Precambrian basement was located at least $250 \mathrm{~km}$ to the east (Hervé et al., 1982). The absence of detailed palaeogeographic studies on these Triassic sediments makes it impossible to tell if this Precambrian basement was the source area of the Triassic basins. Nevertheless, the excess radiogenic argon cannot be denied, leading to older ages which lack geological meaning. In this sense, the effect of excess ${ }^{40} \mathrm{Ar}$ on $\mathrm{K}-\mathrm{Ar}$ dates is most noticeable in minerals having low $\mathrm{K}$ content. In fact, all the older radiometric ages have been obtained from samples having lower $\mathrm{K}$ contents (1.56\% in sample $\mathrm{H} 3-10$ and $1.74 \%$ in sample H618). Cordierite, tourmaline and/or pyroxene are frequently present in the Palaeozoic rocks belonging to the basement. However, no evidence of these minerals was detected in the XRD analyses carried out in the Triassic sediments (Belmar et al., 2002). In consequence, even if the Precambrian rocks were located $\sim 250 \mathrm{~km}$ away during the Triassic depositional basins, these rocks would be the only possible source area for these sedimentary basins.

With respect to the age of $174 \pm 5 \mathrm{Ma}$ for the whole-rock sample H4-02, it is necessary to take into account the thermal event related to contact metamorphism (as shown by a series of parameters discussed above) resetting previous older ages. The temperature determination of $655-691{ }^{\circ} \mathrm{C}$ detected in the surrounding rock by the amphiboleplagioclase geothermometer (Belmar et al., 2002) is higher than the critical temperature for the total Ar resetting $\left(260 \pm 30^{\circ} \mathrm{C}\right.$, Hunziker et al., 1986). Gana \& Hervé (1983) published K-Ar ages of $165 \pm 5 \mathrm{Ma}$ (biotite) and $175 \pm 5 \mathrm{Ma}$ (hornblende) for the plutonic rocks which intrude the Triassic sediments. These ages fit well with the $174 \pm 5 \mathrm{Ma}$ obtained for sample H4-02, belonging to the contact aureole (Fig. 1, area d), and constrain the contact metamorphism event.

\section{Interpretation of $K$-Ar ages for the $<2 \mu \mathrm{m}$ fraction}

The K-Ar ages of the anchizonal Triassic-Jurassic shale measures on the $<2 \mu \mathrm{m}$ size fractions vary between 206 to $181 \mathrm{Ma}$ (Table 2). For these samples, a well control of metamorphism is summarized in Table 1. Maximum temperature estimations during the very low-grade burial 
metamorphism in the study area probably did not exceed $190^{\circ} \mathrm{C}$ with the exception of the contactmetamorphism aureoles (Belmar et al., 2002). According to Hunziker et al. (1986), a complete outgasing of ${ }^{40} \mathrm{Ar}$ in case of $<2 \mu \mathrm{m}$ size illite grains might be produced at temperatures of $\sim 260 \pm 30^{\circ} \mathrm{C}$. This indicates that the temperature of the lowanchizonal metamorphism in the study area might be insufficient to reach the total resetting of the $\mathrm{Ar}$ in the system in the newly formed $<2 \mu \mathrm{m}$ size illite. Therefore we consider the K-Ar determination of $181 \pm 6,184 \pm 6$, and $184 \pm 4$ (Table 2 and Fig. $3 b$ ) to correspond to the peak of maximum burial-induced heating and pressure conditions which, according to Belmar et al. (2002), were $190 \pm 10^{\circ} \mathrm{C}$ and $\geqslant 1.3$ kbar.

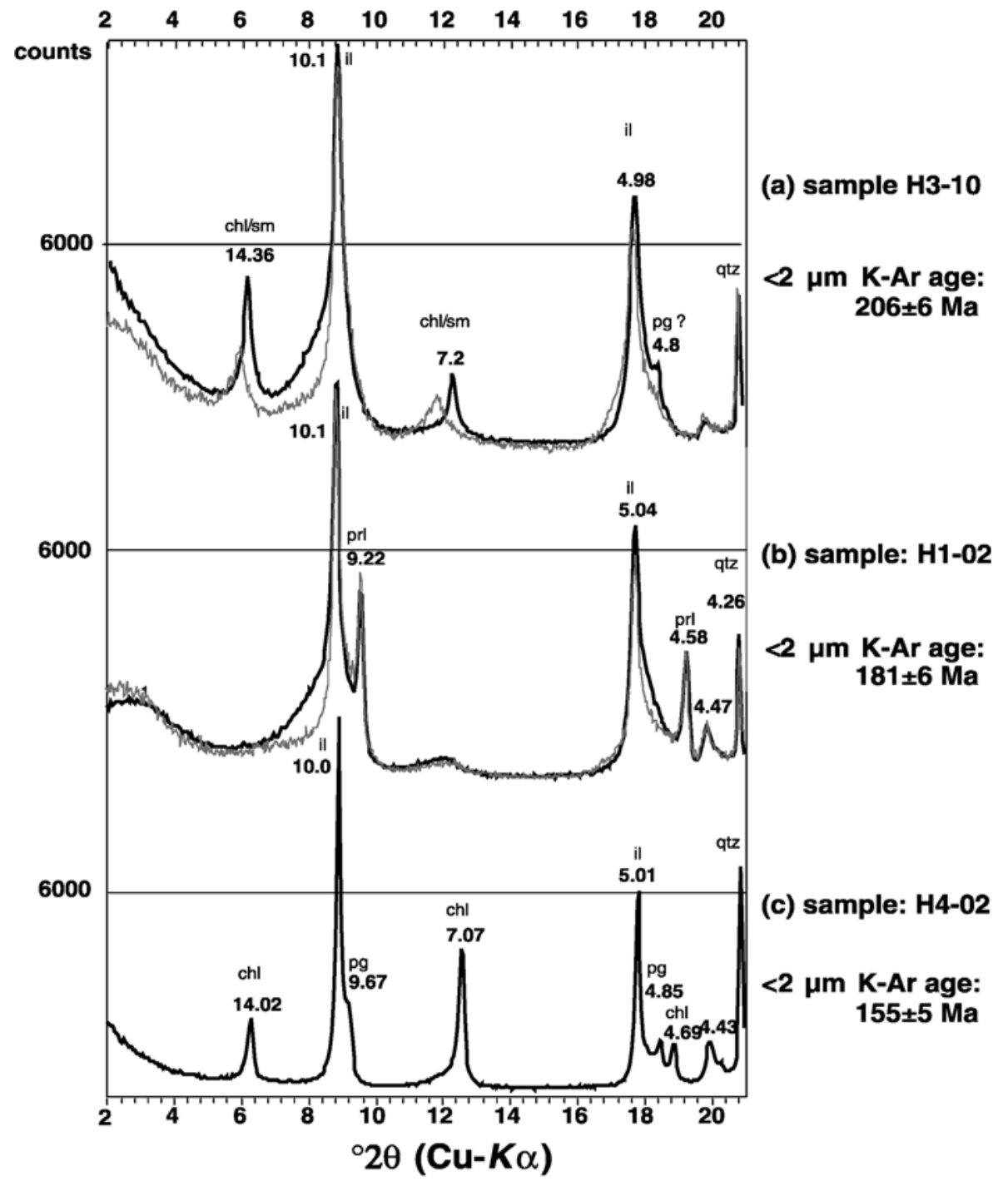

FIG. 3. Representative XRD patterns of the $<2 \mu \mathrm{m}$ fraction. Air-dried and glycolated patterns are shown by thicker and thinner lines, respectively. (a) Sample H3-10 from the diagenetic-anchizone boundary; illite crystallinity $(\mathrm{KI})=0.36 \Delta^{\circ} 2 \theta, R_{\max }=3.8 \%$. (b) Sample H1-2, low anchizone; KI $=0.33 \Delta^{\circ} 2 \theta, R_{\max }=3.9 \%$. (c) Sample H4-2, epizone; KI $=0.23 \Delta^{\circ} 2 \theta, R_{\max }=5.6 \%$. Chl = chlorite, il = illite, $\mathrm{pg}=$ paragonite, $\mathrm{prl}=$ pyrophyllite, $\mathrm{qtz}=$ quartz. Samples are ordered from north to south. 
In sample $\mathrm{H} 3-10$, the $<2 \mu \mathrm{m}$ size fraction give an older age of $206 \pm 6 \mathrm{Ma}$ (Table 2 and Fig. 3a). This sample is representative of an area mainly dominated by diagenetic conditions (Fig. 1, area a). With this constraint, the age obtained suggests that the remaining clay materials are of detrital origin and its $\mathrm{K}-\mathrm{Ar}$ system was not completely reset. Consequently, the $206 \pm 6 \mathrm{Ma}$ age could be interpreted as a mixture of anchizonal metamorphism and diagenesis, but dominated by the latter. This radiometric age of $\sim 206 \mathrm{Ma}$, obtained from Triassic sediments, coincides with the Triassic-Jurassic boundary (Geological Time Scale of the Geological Society of America, 1999) and could be interpreted as a real diagenetic age.

Nevertheless, contamination by a small amount of old detrital mica ( $76 \% 2 \mathrm{M}_{1}$ polytype and anomalous high KI values, Table 1) would indicate a mixed age between a detrital high-crystallinity phase and neoformed illite. According to Środon (2002) and Środoń et al. (2002), in the case of mixed ages, a non-linear relationship between them and proportions of components observed.

Finally, significantly younger age data $(155 \pm 5 \mathrm{Ma})$ were obtained in the epizonal Jurassic sample H4-2 (KI $=0.23)$ located in the area of influence of contact metamorphism (Fig. 1, area d). This age is significantly younger than the wholerock age (174 $\pm 5 \mathrm{Ma})$ and younger than the ages of the plutonic rocks (165-175 Ma). Thus, a later, local, hydrothermal(?)-related event, with younger, newly formed $<2 \mu \mathrm{m}$ illite (Fig. 3c), could be invoked to explain this age.

\section{Geological implications}

The geochronological results obtained in this work allow us to propose some geodynamic considerations in the evolution of the TriassicJurassic volcano-sedimentary basins in the Coastal Range of central Chile. Assuming a Carnian-Norian age $(\approx 220 \mathrm{Ma})$ for the deposition of the studied Triassic sediments, a time interval of $\sim 40 \mathrm{Ma}$ can be obtained between deposition and anchizonal very low-grade metamorphism. Belmar et al. (2002) estimated an overburden of $\sim 4.8 \mathrm{~km}$ for the anchizonal conditions, corresponding to a high geothermal gradient of $>35^{\circ} \mathrm{C} / \mathrm{km}$. With these figures, a subsidence rate in this extensional geodynamic setting of $\sim 120 \mathrm{~m} / \mathrm{Ma}$ can be calculated. This value fits with the proposed interval of $100-300 \mathrm{~m} / \mathrm{Ma}$ for the subsidence in the intra-arc basin of the Coastal Range of central Chile during the Jurassic and Early Cretaceous (Vergara et al., 1995). In both cases, the very low-grade metamorphism could be dominated not only by burial but also controlled by the high regional thermal anomaly related to extension.

\section{CONCLUSIONS}

Even with a limited number of samples, K-Ar dating of Triassic-Jurassic of very low-grade metapelite $\left(T \approx 190^{\circ} \mathrm{C}, P \approx 1.3 \mathrm{kbar}\right)$ from the Coastal Range in central Chile permits the identification of at least four different processes. (1) Dating of the $<2 \mu \mathrm{m}$ size fraction reveals the very low-grade metamorphic process. K-Ar ages ranging from 181 to $184 \mathrm{Ma}$ for anchizonal samples (e.g. sample H1-2, Fig. 3) are interpreted as the best estimate of a burial metamorphic event. (2) The $<2 \mu \mathrm{m}$ size fraction dating of sample H3-10 (206 Ma), belonging to an area dominated by diagenetic conditions, is interpreted as the timing of deposition and correlated with the diagenetic mineralogy of the sample. (3) The whole-rock K-Ar age of $174 \pm 5 \mathrm{Ma}$ (sample H4-2) is interpreted as belonging to the contact metamorphic zone due to the intrusion of Jurassic plutons, dated at $165 \pm 5 \mathrm{Ma}$ (biotite K-Ar) and $175 \pm 5 \mathrm{Ma}$ (hornblende K-Ar). The $655-691^{\circ} \mathrm{C}$ high-temperature conditions estimated for the contact metamorphism were responsible for a possible reset of the K-Ar system. Additionaly, sample H4-02 has a Kübler Index value typical of the upper epizone condition and the coal-rank also indicates high thermal conditions. (4) The $<2 \mu \mathrm{m}$ size fraction dating of sample H4-02 $(155 \pm 5 \mathrm{Ma})$ could be interpreted as consequence of younger Ar resetting related to minor local intrusions.

$\mathrm{K}$-Ar whole-rock dating of samples affected by very low-grade metamorphism below the critical temperature of $260 \pm 30^{\circ} \mathrm{C}$ may provide some information about the source area. The origin of the very low-grade metamorphism could be the consequence of both burial and an anomalous high geothermal gradient of $>35^{\circ} \mathrm{C} / \mathrm{km}$, related to a geotectonic extensional setting.

In conclusion, the combination of dating the $<2 \mu \mathrm{m}$ size fraction of the Triassic-Jurassic metapelitic sequences from the Coastal Range of central Chile is an adequate method to constrain the time interval between the diagenesis (206 Ma) and the anchizonal very low-grade metamorphism 
(181-184 Ma) and to calculate the rate of subsidence $(\sim 120 \mathrm{~m} / \mathrm{Ma})$ for these extensional Triassic-Jurassic basins.

\section{ACKNOWLEDGMENTS}

We would like to thank the Servicio Geológico de Chile for laboratory support, and especially to Paula Cornejo and Steve Matthews. The MECESUP Grant $\mathrm{Nr}$ 0010 and an internal project of SERNAGEOMINDepartamento de Geología, Universidad de Chile financially supported this study. We also thank to the Acción Especial programme of the Plan Propio of Granada University (Spain). Critical and constructive comments and suggestions by Katja Deckart, M.D Ruiz-Cruz and N. Clauer improved an earlier version of this paper.

\section{REFERENCES}

Arkai P., Balogh K. \& Dunkl I. (1995) Timing of lowtemperature metamorphism and cooling of the Paleozoic and Mesozoic formations of the Bükkium, innermost Western Carpathians, Hungary. Geologische Rundschau, 84, 334-344.

Belmar M., Schmidt S.Th., Ferreiro-Mählmann R., Mullis J., Stern W.B. \& Frey M. (2002) Diagenesis, low-grade and contact metamorphism in the Triassic-Jurassic of Vichuquén-Tilicura and Hualeñé-Gualleco Basins, Coast Range of Chile. Schweizeriche Mineralogische und Petrographische Mitteilungen, 82, 375-392.

Bravo P. (2001) Geología del Borde Oriental de la cordillera de la costa entre los Ríos Mataquito y Maule, VII región. Memoria de Titulo, Universidad de Chile, Departamento de Geología, Santiago, Chile.

Cathelineau M. (1988) Cation site occupancy in chlorites and illites as a function of temperature. Clay Minerals, 23, 471-485.

Clauer N. \& Chaudhuri S. (1999). Isotopic dating of very low-grade metasedimentary and metavolcanic rocks: techniques and methods. Pp. 202-226 in: Low-grade Metamorphism (M. Frey and D. Robinson, editors). Blackwell Science, Oxford, UK.

Clauer N., Rais N., Schaltegger U. \& Piqué A. (1995) KAr systematic of clay-to-mica minerals in a multistage low-grade metamorphic evolution. Chemical Geology, 124, 305-316.

Clauer N., Środoń J., Francu J. \& Šucha V. (1997) K-Ar dating of illite fundamental particles separated from illite/smectite. Clay Minerals, 32, 181-196.

Corvalán J. (1976) El Triásico y Jurásico de VichuquénTilicura y de Hualañé, provincia de Curicó. Implicaciones Paleogeográficas. Pp. A137-A154 in: Primer Congreso Geológico Chileno, Santiago, Chile.Vol. 1.

Corvalán J. (1982) El Límite Triásico-Jurásico en la Cordillera de la Costa de las Provincias de Curicó y Talca. Pp F63-F85 in: Tercer Congreso Geológico Chileno, Concepción, Chile, Vol. 3.

Corvalán J. (1994) El Triásico y Jurásico de Vichuquén, Hualañé, Curepto y Gualleco. Unpublished map, Servicio Nacional de Geología y Minería.

Dalla Torre M., Stern W.B. \& Frey M. (1994) Determination of white K-mica polytype ratios: Comparison of different XRD methods. Clay Minerals, 29, 717-726.

Gana P. \& Hervé F. (1983) Geología del Basamento Cristalino en la Cordillera de la Costa entre los ríos Mataquito y Maule, VII Región, Chile. Revista Geológica de Chile, 19/20, 37-56.

Gonzales-Bonorino F. (1971) Metamorphic facies series of the crystalline basement of central Chile. Journal of Petrology, 12, 149-175.

Gonzales-Bonorino F. \& Aguirre L. (1970) Metamorphic facies series of the crystalline basement of Chile. Geologische Rundschau, 59, 979-994.

Hervé F. (1988) Late Paleozoic Subduction and Accretion in Southern Chile. Episodes, 11, 183-188

Hervé F., Munizaga F., Godoy E. \& Aguirre L. (1974) Late Paleozoic $\mathrm{K} / \mathrm{Ar}$ ages of blueschists from Pichilemu, central Chile. Earth and Planetary Science Letters, 23, 261-264.

Hervé F., Kawashita K. \& Munizaga F. (1982) Edades $\mathrm{Rb} / \mathrm{Sr}$ de los cinturones metamórficos pareados de Chile Central. Pp. D116-D135 in: Tercer Congreso Geológico Chileno, Concepción, Chile, vol. 3.

Holland T. \& Blundy J. (1994) Non-ideal interactions in calcic amphiboles and their bearing on amphiboles plagioclase thermometry. Contributions to Mineralogy and Petrology, 116, 433-447.

Hunziker J.C., Frey M., Clauer N., Dallmeyer R.D., Friedrichsen H., Flehmig W., Hochstrasser K., Roggwiler P. \& Schwander H. (1986) The evolution of illite to muscovite: mineralogical and isotopic date from the Glarus Alps, Switzerland. Contributions to Mineralogy and Petrology, 92, 157-180.

Kisch H. (1991). Illite crystallinity: recomendations on sample preparation, X-ray diffraction setting, and interlaboratory samples. Journal of Metamorphic Geology, 9, 665-670.

Kübler B. (1967) La crystallinité de l'illite et les zones tout à fait supérieures du métamorphisme. Étages tectoniques. Colloque de Neuchâtel, 105-122.

Kübler B. (1984) Les indicateurs des transformations physiques et chimiques dans la diagenèse, temperature et calorimétrie. Pp. 489-596 in: Thérmométrie et Barométrie Géologiques (M. Lagache, editor). Societé Française de Minéralogie et Cristallographie, Paris. 
Martin M.W., Kato T.T., Rodriguez C., Godoy E., Duhart P., McDonough M. \& Campos A. (1999) Evolution of the late Paleozoic accretionary complex and overlying forearc-magmatic arc, south central Chile $\left(38^{\circ}-41^{\circ} \mathrm{S}\right)$ : Constraints for the tectonic setting along the southwestern margin of Gondwana. Tectonics, 18, 582-605

Merriman R.J. \& Frey M. (1999) Patterns of very lowgrade metamorphism in pelitic rocks. Pp. 61-107 in: Low-grade Metamorphism (M. Frey and D. Robinson, editors). Blackwell Science Ltd., Oxford, UK.

Moore D.M. \& Reynolds R.C. (1997) X-ray Diffraction and the Identification and Analysis of Clay Minerals. Oxford University Press, New York, 378 pp.

Morel R. (1981) Geología del sector norte de la hoja Gualleco, entre los $35^{\circ} 00^{\prime}$ y los $35^{\circ} 10^{\prime}$ latitud sur, provincia de Talca, VII Región, Chile. Tesis de Grado, M.Cs., Universidad de Chile, Departamento de Geología, Santiago.

Munizaga F., Aguirre L. \& Hervé F. (1973) Rb/Sr ages of rocks from the Chilean metamorphic basement. Earth and Planetary Science Letters, 18, 87-91.

Munizaga F., Hervé F., Drake R., Pankhurst R.J., Brook M. \& Snelling N. (1988) Geochronology of the Lake Region of south-central Chile $\left(39^{\circ}-42^{\circ} \mathrm{S}\right)$ : Preliminary results. Journal of South American Earth Sciences, 1, 309-316.

Pollastro R.M. (1993) Considerations and applications of the illite/smectite geothermometer in hydrocarbon-bearing rocks of Miocene to Mississippian age. Clays and Clay Minerals, 41, 119-133.

Steiger R.H. \& Jäger E. (1977) Subcommission on geochronology: convention on use of decay con- stants in geo- and cosmochronology. Earth and Planetary Science Letters, 36, 359-362.

Środoń J. (2002) Quantitative mineralogy of sedimentary rocks with emphasis on clay and with applications to K-Ar dating. Mineralogical Magazine, 66, 677-687.

ŚrodońJ., Clauer N. \& Eberl D.D. (2002) Interpretation of K-Ar dates of illitic clays from sedimentary rocks aided by modelling. American Mineralogist, 87, $1528-1535$.

Thiele R. \& Morel R. (1981) Tectonica Triásico-Jurásica en la Cordillera de la Costa, al norte y sur del Río Mataquito $\left(34^{\circ} 45^{\prime}-35^{\circ} 15^{\prime}\right.$ Lat. S), Chile. Revista Geológica de Chile, 13/14, 49-61.

Vergara M., Levi B., Nyström J. \& Cancino A. (1995) Jurassic and Early Cretaceous island arc volcanism, extension, and subsidence in the Coast Range of central Chile. Geological Society of America Bulletin, 10, 1427-1440.

Willner A., Hervé F. \& Massonne H. (2000) Mineral chemistry and pressure-temperature evolution of two contrasting high-pressure-low-temperature belts in the Chonos Archipielago, Southern Chile. Journal of Petrology, 41, 309-330.

Willner A.P., Thomson S.N., Kröner, A., Wartho J.-A., Wijbrans J. \& Hervé F. (submitted). Time markers for the evolution and exhumation history of an Upper Paleozoic paired metamorphic belt in Central Chile $\left(34^{\circ}-35^{\circ} 30^{\prime}\right.$ S). Journal of Petrology.

Zhao M.W., Ahrendt H. \& Wemmer K. (1997) K-Ar systematic of illite/smectite in argillaceous rocks from the Ordos basin, China. Chemical Geology, 136, 153-169. 